\section{Presence and extension of the attributes of primary health care in public dental services in Porto Alegre, Rio Grande do Sul State, Brazil}

\author{
Presença e abrangência de atributos da atenção \\ primária em saúde em serviços públicos de \\ saúde bucal em Porto Alegre, Rio Grande \\ do Sul, Brasil
}

\author{
Presencia y extensión de los atributos de la \\ atención primaria de salud en servicios \\ dentales públicos de Porto Alegre, \\ Río Grande do Sul, Brasil
}

Débora Deus Cardozo 1

Juliana Balbinot Hilgert 1

Caroline Stein 1

Lisiane Hauser 1

Erno Harzheim 1

Fernando Neves Hugo 1 doi: 10.1590/0102-311X00004219

\begin{abstract}
The objective was to compare the presence and extension of primary health care (PHC) in oral health services using the PHC attributes according to three different types of PHC organizational arrangements: Family Health Strategy (FHS), Community Health Service (CHS) and Traditional Primary Care (TPC). This is a cross-sectional study carried out between 2011-2013, following a cluster random sampling strategy. Adult users were interviewed from 15 health services of that 6 were managed by the CHS, 4 by the FHS and 5 by the TPC and which had the same oral health team for at least two years. The final sample was 407 users interviewed using the Primary Care Assessment Tool - Oral Health of Adults evaluation instrument and a sociodemographic questionnaire. PHC scores were calculated and transformed on a scale ranging from 0 to 10. For high scores, the cut-off point > 5.5 was used. Most of the interviewees were females, for the three types of services. The performance of CHS and FHS was higher than those of TPC in almost all attributes ( $p<$ 0.05). The extent of PHC attributes in services was poor (overall highest score was 5.75 in CHS). The CHS was the only service witch half of the users (83; 49.1\%) rated oral health services as having a high overall score for PHC. It is concluded that there were differences among the organizational arrangements of PHC oral health services, however, there is much to be improved in the orientation of dental care services for PHC. More studies are necessary to evaluate the differences in PHC services considering oral health.
\end{abstract}

Primary Health Care; Oral Health; Health Services Evaluation; Dental Health Services

\author{
Correspondence \\ C. Stein \\ Universidade Federal do Rio Grande do Sul. \\ Rua Ramiro Barcelos 2492, Porto Alegre, RS 90035-004, Brasil. \\ csteinodonto@hotmail.com \\ 1 Universidade Federal do Rio Grande do Sul, \\ Porto Alegre, Brasil.
}




\section{Introduction}

Over the course of its history, the Brazilian health system was characterized by a hospital-centered organizational arrangement of care, focused on medical consultation 1. This type of care, focused on consultation, is characterized as being disease-centered, focused on the diagnosis and treatment, it is also biologic, with emphasis on technicality 2 . The center of care is the diseased person. Based on this, the actions of recovery and rehabilitation of the disease were prioritized, at the expense of health promotion and protection actions 3 .

Since this organizational arrangement did not consider the improvement of health indicators, it was widely questioned. Therefore, strategies for deploying an organizational arrangement of care focused on providing access, team work, population's engagement and health promotion were needed 3. The transformation of the organizational arrangement of care involves the implementation of changes in the work process, both in relation to its purpose and goals, and also to its structural elements 4 .

Nowadays, in Brazil, mainly two different primary health care (PHC) organizational arrangements coexist: Traditional Primary Care (TPC), that works without clear programmatic guidance; and Family Health Strategy (FHS), that works according to the Brazilian National Primary Health Care Policy (PNAB) 5 and the Brazilian National Oral Health Policy (PNSB) 6. The change of the health care organizational arrangement started after the implementation of the Brazilian Unified National Health System (SUS) and, mainly, after the establishment of the Family Health Program (FHP), launched in 1994 7, which has been expanded and rebranded as FHS 8.

The Brazilian Ministry of Health affirms that the FHS is their main strategy for expansion, qualification, consolidation and organization of PHC 8 . This organizational arrangement would favor a reorientation of the work process which has the greatest potential to extend the principles, guidelines and foundations of PHC, in order to amplify the resolution and impact on the health of individuals and communities 9 .

As for oral health, the need to increase the population's access to oral health services was identified, based on the results of the Brazilian National Household Sample Survey (PNAD - 1998) 10, which showed that $18.5 \%$ of Brazil's population from that period had never had an appointment with a dentist, in addition to a historic process that lasted many years and involved several social actors who contributed to change the future of oral health services in Brazil 11. The Ministry of Health answered by incorporating the oral health team (OHT) into the FHS in December 2000 12. The first OHT has been deployed in 2001 (84 in modality I and 40 in modality II) and, in 2019, 26,502 OHT were already working in FHS, serving more than 83 million people, which correspond to $40 \%$ of the country's population 13 .

In Porto Alegre (Rio Grande do Sul State), in addition to the TPC and FHS that also coexist in the entire country, there is also the Conceição Hospital Group's Community Health Service (CHG-CHS). This service has been in operation since 1982 and is directly connected to the Ministry of Health, which works according to a PHC expanded, more close to the comprehensiveness of care 14 . The CHS is an organizational arrangement for Brazil and professionals related to it have helped to create the FHP alongside the Ministry of Health.

In 2012, in a cross-sectional study conducted with medical professionals and nurses, Castro et al. 15 compared the different PHC services of Porto Alegre, using the Primary Care Assessment Tool (PCATool), professional version, and showed that the TPC has a lower degree of orientation towards PHC, with the CHS, showing the highest degree of orientation 15. In relation to the degree of orientation towards the PHC, in studies that have compared the three types of services that exist in Porto Alegre, according to the perspective of their users, CHS, FHS and TPC, Oliveira 16, in 2007, showed that CHS presented higher scores, followed by the FHS organizational arrangement; on the other hand, the TPC obtained the lowest levels in the overall score. Another important study evaluated the quality of PHC using PCATool's managers and dentists version and the use of oral health services by preschool children users of FHS, found better results for the attributes of PHC in oral health setting was related to the effective use of the oral health services ${ }^{17}$. It is important to identify more effective arrangements of PHC in oral health, especially in view of the essential attributes of PHC. Although the PNSB was launched in 2004, to date most studies have used data from the Brazilian National Program 
for Improving Access and Quality to Primary Care (PMAQ). However, independent evaluations using instruments with good psychometric properties are fundamental to support the development of PHC in oral health in Brazil. The hypothesis of this study is that, for oral health, the preeminence of the FHS and CHS services over TPC, in what concerns the presence of PHC attributes, happens to be true, justifying the choice of this organizational arrangement as the ideal one for the reorientation of health care. Thus, the aim of this study is to assess and compare the presence and extension of the PHC attributes in different types of PHC organizational arrangement, provided by three dental services in Porto Alegre (TPC, FHS and CHS).

\section{Methods}

\section{Design and setting}

This is a population-based cross-sectional study, carried out in the city of Porto Alegre between October 2011 and May 2013. This is a secondary study, from the primary that was the validity of the instrument Primary Care Assessment Tool - Oral Health of Adults (PCATool-OH). The study was developed in three different organizational arrangements of PHC: TPC, FHS and CHS. TPC do not follow a programmatic guidance of health care; FHS follow the orientations and principles of PNAB 5 and PNSB 6. The CHS is a PHC with more consolidated comprehensiveness of care and constituted by teams formed by medical doctors, dentists, nurses, nursing assistants and technicians, dental hygienists, psychologists, social workers and community health workers in all services, and nutritionists and pharmacists who work supporting these services 14 . In this setting, for example, social workers support the construction of therapeutic projects by the OHT for vulnerable families, something very important and that does not occur in the FHS. In addition, CHS is a training center of human resources for SUS, through the Integrated Health Residency Program 14.

\section{Ethical aspects}

The research project Presence and Extent of the Attributes of Primary Care in Public Dental Services of Porto Alegre and Its Relationship with Oral Health Related to the Quality of Life of Patients was submitted and approved (n. 001.043203.10.8) by the Ethics Committee of the Municipal Government of Porto Alegre and of the GHC. The interviews with the patients from the services were carried out after reading and signing the Informed Consent Form (ICF) and were performed according to the ethical principles established in the Declaration of Helsinki and Brazilian legislation.

\section{Participants}

Adult users aged 18 years or more, assigned to PHC services who were users of primary care dentistry (PCD), that used the service at least once during the 24 months prior to the study. Patients who reported never having used the PHC service for dental appointments and those who reported having looked for private services were excluded from the sample.

\section{Sample}

Considering that this study is secondary from the study of validation of the PCATool-OH, a cluster random sampling was used in multiple stages. Thus, 15 health units of three types of primary care services which provided oral health services were selected. The eligibility criteria for the primary care services were: having an oral health team with the same dentist for at least two years; having a dental office in the service; the dentist works in the same service where he is allocated. Of the 15 FHS services set out in Porto Alegre at the beginning of the study (a population coverage of 4\%), only 5 met the eligibility criteria and thus were automatically selected. From the 78 TPC and 11 CHS, 5 of each were randomly drawn. During data collection, one dentist working in an FHS was relocated and the service was removed and replaced by a GHC service selected randomly. Thus, there were 15 health 
services, of which 6 were managed by the CHS, 4 by the FHS and 5 by the TPC were included in this study. From the maps of census sectors of the areas allocated to each service, a sector was randomly drawn, then a block of the sector, a corner of the block and a house between the first two of this corner. From each house, only one user who fulfilled the inclusion criteria was interviewed. If more than one person met the inclusion criteria, a drawn was carried out. The sample size was obtained from a pilot study with 30 full interviews, in order to assess if that questionnaire was capable of establishing a distinction between the presence and degree of the attributes of PHC between different organizational arrangements of oral health care in Porto Alegre. In order to achieve the goals of validation of the instrument PCATool-OH, the sample was estimated at 405 individuals (5 respondents per item of the PCATool-OH).

\section{Variables and sources of data/measurement}

To obtain data, the interviews were conducted by researchers, who were trained beforehand, using a structured questionnaire, and the interviews were made after reading and signing the ICF, having an average length of one hour. Altogether, 17 interviewers participated in this study's data collection. The training of researchers happened before the study's beginning, using three meetings with a workload of four hours each, in which they received guidance on the methodology for applying, handling and completing the questionnaires. A field manual was outlined, "targeting" researchers, and during training the interviewers conducted simulated interviews. To assess the training, a pilot field trip was held, in pairs, where one researcher applied the questionnaire to a user, while the other was assessing it.

A structured questionnaire was used to collect data related to: (i) sociodemographic variables: age (in years), sex (male; female) and skin color (white; non-white); (ii) socioeconomic variables: economic classification (AB; CDE, according to the Brazilian Association of Research Companies - ABEP 18), income (Brazilian Reais: until 500; 501 to 800; > 800) and education (years of study: up to 4 years; 5 or more); (iii) type of services: FHS, TPC and CHS; (iv) social support variables: conjugal situation (with partner; without partner) and unemployment in the family; (v) health status variables: hypertension (yes; no), diabetes (yes; no).

For the measurement of the presence and extension of the attributes of the PHC the instrument PCATool-OH version was used. This questionnaire comprises 81 questions and the answers are presented on a 4-point Likert scale, ranging from "absolutely" (4) to "certainly not" (1). The instrument is based on evaluating the PHC from the six attributes of PHC, which four are core attributes (access, continuity, comprehensiveness, and coordination of care) and two are ancillary attributes (familycenteredness and community orientation). To obtain the scores for each attribute one calculates the average of the items that are part of each. The score is obtained based on the average score of the core attributes (4 attributes) and the overall score (6 attributes) obtained from the average scores of the 6 attributes. After that, the values are transformed to fit into a 0 to $10 \mathrm{scale}$. Even though it is recommended a cut-off point of $>6.5$ for the high score of PHC 16, in this study a $>5.5$ cut-off point was used, due to the data distribution. To obtain the socio-demographic data, questions on income, education, presence of chronic diseases and classification of the ABEP economic class were used.

The general questionnaire was structured into the designer submodule of the Teleform software (http://www.opentext.com). The questionnaires were scanned and the transfer of information into a spreadsheet of data was carried out using the verification process of images, relying on the reader and verify submodules of the Teleform. This procedure replaces the double input. Then, the data were exported to a database of the SPSS 16.0 software (https://www.ibm.com/).

\section{Statistical methods}

A descriptive analysis of all variables and chi-square for categorical variables were also carried out. In order to compare the scores of the attributes between the different types of service, the Anova test was used, followed by Sheffé's post hoc, when there was a rejection of the null hypothesis. In order to analyze the variables associated with the high degree of orientation towards the PHC, a Poisson regression with robust variance was adjusted, abiding by a hierarchical structure. Variables that 
represented socioeconomic, demographic characteristics, social support and health status were split into blocks of relationship with the degree of orientation towards PHC, under a conceptual hierarchical model, where core attributes are access, continuity, coordination and comprehensiveness; and ancillary attributes are family-centeredness and community orientation 19.

Under this structure of analysis, the association between the explanatory variables and the outcome (orientation towards PHC) was assessed within the hierarchical block to which they belong. A significance of $\leq 0.20$ was implemented for the permanence of the variable in the multivariate model, in accordance with the adjustment observed in its hierarchical level. The multivariate model resulting from this adjustment includes all variables that were significant.

\section{Results}

During the data collection, 1,943 people were contacted. Of these, 81 were visited three times and were not found at home; 6 refused to participate and 1,449 could not be interviewed because they had never used the services to have an appointment with a dentist. Thus, the final sample comprised 407 interviewees.

When characterizing the population studied according to age (Table 1), users of TPC had the lowest average age, with 44.5 years $(\mathrm{SD}=15.88)$ and those of the CHS had the highest, with an average of 53.6 years $(\mathrm{SD}=17.33)$. Most of the interviewees were females, for the three types of services. Users of CHS had the largest proportion of whites among the services (66.2\%) and those of the TPC had the lowest proportion of patients who were part of $\mathrm{AB}$ classes (19.42\%), whereas those of CHS presented $30.53 \%$ of patients who fall into this category. Education and income varied as well among the types of PHC services, with mean of years of study $7.47(\mathrm{SD}=3.46)$ and $7.74(\mathrm{SD}=3.43)$ to individuals from FHS and TPC respectively and the mean of income was higher in users from CHS (BRL 801.63) and smaller to TPC (BRL 670.82).

In order to establish a comparison between the services in all of their aspects, the scores of each attribute of PHC were taken into account, as well as the degrees of affiliation towards health services and the core attributes and overall scores for each service. Table 1 presents a comparison of the scores per attribute between the services. For the core attributes and overall scores, the significant and larger differences in the degree of orientation towards PHC, CHS and FHS, in relation to TPC $(\mathrm{p}<0.01)$, were highlighted, with the exception of the attribute coordination-information system and degree of affiliation towards the services, which did not show significant differences between the services. For all other attributes studied, the performance of CHS and FHS was statistically higher than the one of TPC.

Regarding the classification of services between the high and the low overall scores, among users interviewed that rated oral health services as having a high overall score for PHC only $27.8 \%$ of users of TPC, and $23.1 \%$ of users of FHS rated this service as having a high degree of orientation towards PHC. On the other hand, CHS was the service where $49.1 \%$ users rated oral health services as having a high overall score for PHC (Table 2).

Using a univariate analysis, it was observed that, among the socioeconomic and demographic variables, only income, in its lower third (up to BRL 500) was actually associated with the high overall score of orientation towards PHC $(\mathrm{p}<0.06)$ (Table 3$)$. The social support variables were not associated with outcome, whereas the type of service was, solely by itself, a variable associated with a high overall score of PHC ( $\mathrm{p}<0.04)$. From the variables which represent the health status, hypertension $(p=0.024)$ and diabetes $(p=0.069)$ were associated with a high overall score of orientation towards PHC. Regarding the multivariate model, the variables which remained significant in relation to the high overall score were the type of service, hypertension and diabetes. The presence of diabetes increases by $16 \%$ the prevalence of a strong orientation towards PHC, while the absence of hypertension increases by $16 \%$ the prevalence of the high score of PHC (Table 3). 
Table 1

Socioeconomic characteristics, demographic, health status and utilization of the primary care dentistry services, and scores of attributes of primary health care (PHC) from Primary Care Assessment Tool - Oral Health of Adults (PCATool-OH), between different primary care services. Porto Alegre, Rio Grande do Sul State, Brazil, 2011-2013.

\begin{tabular}{|c|c|c|c|}
\hline & $\begin{array}{c}\text { FHS }(n=95) \\
\text { Mean (SD) or \% }\end{array}$ & $\begin{array}{c}\text { TPC }(n=161) \\
\text { Mean }(S D) \text { or \% }\end{array}$ & $\begin{array}{c}\text { CHS }(n=151) \\
\text { Mean }(S D) \text { or } \%\end{array}$ \\
\hline \multicolumn{4}{|l|}{ Variables } \\
\hline Age & $47.3(15.65)$ & $44.5(15.88)$ & $53.6(17.33)$ \\
\hline \multicolumn{4}{|l|}{ Sex } \\
\hline Male & 17.90 & 18.63 & 20.52 \\
\hline Female & 82.10 & 81.37 & 79.48 \\
\hline \multicolumn{4}{|l|}{ Skin color } \\
\hline White & 58.94 & 55.90 & 66.22 \\
\hline Non-white & 41.06 & 44.10 & 33.78 \\
\hline \multicolumn{4}{|l|}{ Economic classification } \\
\hline$A B$ & 25.33 & 19.42 & 30.53 \\
\hline $\mathrm{CDE}$ & 74.67 & 80.58 & 69.47 \\
\hline Income & $694.13(630.83)$ & $670.82(620.79)$ & $801.63(796.12)$ \\
\hline Education (years of study) & $7.47(3.46)$ & $7.74(3.43)$ & $7.57(3.69)$ \\
\hline \multicolumn{4}{|l|}{ Health status } \\
\hline Hypertension & 37.89 & 31.67 & 39.73 \\
\hline \multirow[t]{2}{*}{ Diabetes } & 16.84 & 8.07 & 11.25 \\
\hline & \multicolumn{3}{|c|}{ PHC scores * } \\
\hline \multicolumn{4}{|l|}{ Attributes of primary care in oral health } \\
\hline Degree of affiliation to the service & 7.02 & 6.43 & 6.84 \\
\hline Accessibility & $3.33 * *$ & 2.43 & $3.43 * *$ \\
\hline Access - utilization & $8.98 * * *$ & 8.38 & $9.36 * *$ \\
\hline Continuity & $5.88 * * *$ & 5.19 & $6.47 * *$ \\
\hline Coordination of care & 5.09 & 2.86 & $4.89 * * *$ \\
\hline Coordination - information systems & 5.43 & 5.35 & 5.80 \\
\hline Comprehensiveness - available services & 5.38 & 4.97 & $5.76 * *$ \\
\hline Comprehensiveness - services provided & $4.83 * * *$ & 3.99 & 4.46 \\
\hline Core attributes & $5.81 * *$ & 5.19 & $5.99 * *$ \\
\hline Family-centeredness & 4.12 & 3.17 & $4.71 * *$ \\
\hline Community orientation & $3.82 * \star$ & 2.13 & $5.07 * *$ \\
\hline Overall score & $5.40 * *$ & 4.63 & $5.75 * *$ \\
\hline
\end{tabular}

CHS: Community Health Service; FHS: Family Health Strategy; SD: standard deviation; TPC: Traditional Primary Care.

* The scores assume values between 0-10;

** Significance by test of Scheffé - p-value $<0.01$;

$* \star *$ Significance by test of Scheffé - $\mathrm{p}$-value $<0.05$.

\section{Discussion}

The OHT included in the FHS have undergone a major increase in number in recent years ${ }^{13}$. However, there is no evaluation research which relies on a validated instrument capable of verifying if this increase in number also matches an increase in the quality of PHC provided by these teams, as supported by the PNAB 5 and PNSB 6 . The results of this study show that the presence and degree of the attributes of PHC were more adequate according to individuals who, in this study, were part of CHS and FHS, when compared to TPC services. These results may work as a theoretical basis for managers to adopt OHT, as a way of expanding PHC in Brazil's oral health. 
Table 2

Distribution of characteristics of the studied population between high and low core attributes and overall scores of primary health care (PHC) from Primary Care Assessment Tool - Oral Health of Adults (PCATool-OH). Porto Alegre, Rio Grande do Sul State, Brazil, 2011-2013.

\begin{tabular}{|c|c|c|c|c|c|c|}
\hline Variables & $\begin{array}{c}\text { High core } \\
\text { attributes score } \\
\mathbf{n}(\%)\end{array}$ & $\begin{array}{c}\text { Low core } \\
\text { attributes score } \\
\mathrm{n}(\%)\end{array}$ & p-value & $\begin{array}{c}\text { High overall } \\
\text { score } \\
\text { n (\%) }\end{array}$ & $\begin{array}{l}\text { Low overall } \\
\text { score } \\
\text { n (\%) }\end{array}$ & p-value \\
\hline \multicolumn{7}{|l|}{ Sociodemographic } \\
\hline \multicolumn{7}{|l|}{ Sex } \\
\hline Male & $44(19.5)$ & $32(18.6)$ & 0.83 & $34(20.7)$ & $43(18.2)$ & 0.53 \\
\hline Female & $182(80.5)$ & $140(81.4)$ & & $130(79.3)$ & $193(81.8)$ & \\
\hline \multicolumn{7}{|l|}{ Skin color } \\
\hline White & $133(58.3)$ & $106(62.0)$ & 0.46 & 99 (59.3) & $142(60.7)$ & 0.78 \\
\hline Non-white & $95(41.7)$ & $65(38.0)$ & & $68(40.7)$ & $92(39.3)$ & \\
\hline \multicolumn{7}{|l|}{ Socioeconomic } \\
\hline \multicolumn{7}{|l|}{ Economic classification } \\
\hline$A B$ & $46(23.5)$ & $40(28.2)$ & 0.33 & $36(26.1)$ & $48(2.04)$ & 0.66 \\
\hline$C D E$ & $150(76.5)$ & $102(71.8)$ & & $102(73.9)$ & $152(76.0)$ & \\
\hline \multicolumn{7}{|l|}{ Income (Brazilian Reais) } \\
\hline Until 500 & $62(30.5)$ & $60(37.0)$ & 0.42 & $42(27.6)$ & $80(37.0)$ & 0.15 \\
\hline $501-800$ & $74(36.5)$ & $54(33.3)$ & & $56(36.8)$ & $73(33.8)$ & \\
\hline$>800$ & $67(33.0)$ & $48(29.6)$ & & $54(35.5)$ & $63(29.2)$ & \\
\hline \multicolumn{7}{|l|}{ Education } \\
\hline Up to 4 years & $54(23.5)$ & $32(18.6)$ & 0.24 & $40(26.1)$ & $48(20.4)$ & 0.44 \\
\hline 5 years or more & $176(76.5)$ & $140(81.4)$ & & $129(76.3)$ & $187(79.6)$ & \\
\hline \multicolumn{7}{|l|}{ Type of service } \\
\hline FHS & $62(26.8)$ & $32(18.6)$ & 0.00 & $39(23.1)$ & $55(23.3)$ & 0.00 \\
\hline TPC & $67(29.0)$ & $93(54.1)$ & & $47(27.8)$ & $114(48.3)$ & \\
\hline $\mathrm{CHS}$ & $102(44.2)$ & $47(27.3)$ & & $83(49.1)$ & $67(28.4)$ & \\
\hline \multicolumn{7}{|l|}{ Social support } \\
\hline \multicolumn{7}{|l|}{ Conjugal situation } \\
\hline With partner & $134(59.0)$ & $94(55.6)$ & 0.50 & $97(58.8)$ & $134(57.5)$ & 0.80 \\
\hline Without partner & $93(41.0)$ & $65(38.0)$ & & $68(41.2)$ & $99(42.5)$ & \\
\hline Unemployment in the family & $50(22.7)$ & $48(28.6)$ & 0.19 & $39(24.2)$ & $61(26.8)$ & 0.57 \\
\hline \multicolumn{7}{|l|}{ Health status } \\
\hline Hypertension & $80(54.4)$ & $66(63.5)$ & 0.42 & $54(52.4)$ & $90(66.7)$ & 0.03 \\
\hline Diabetes & $30(26.3)$ & $15(16.3)$ & 0.08 & $25(28.4)$ & $21(17.9)$ & 0.07 \\
\hline
\end{tabular}

CHS: Community Health Service; FHS: Family Health Strategy; TPC: Traditional Primary Care.

Note: cut-off point to 5.5; 5.6 is high score.

This study used a cut-off point for the high score of PHC in oral health $>5.5$, when the point used for medical and nursing services has a high score $>6.5$. This option was justified due to the low extension of PHC attributes for the oral health services assessed (the overall score ranged between 4.63 and 5.75), something that clearly shows the dichotomy between the idealized organizational arrangement and the organizational arrangement carried out by OHT in services.

When assessing the attributes according to the theoretical framework adopted 19 for this study, one can assess problems associated with the care process currently used by the three types of services. Accessibility was, among the attributes assessed, the one with the worst performance. Nonetheless, there was a significant and greater difference between CHS and FHS, something that can be compared to TPC. A specific data that reflects the lack of accessibility to services was the difficulty in finding patients who had used PHC services to make an oral health appointment. To obtain a bit more than 400 interviews in areas with health services with OHT, 1,943 people were contacted and, among 
Table 3

Variables associated with the high overall score of primary health care (PHC) from Primary Care Assessment Tool - Oral Health of Adults (PCATool-OH). Poisson regression with robust variance.

\begin{tabular}{|c|c|c|c|c|}
\hline \multirow[t]{2}{*}{ Variables } & \multicolumn{2}{|c|}{ Univariate analysis } & \multicolumn{2}{|c|}{ Multivariate analysis } \\
\hline & PR $(95 \% \mathrm{Cl})$ & p-value & PR $(95 \% \mathrm{Cl})$ & p-value \\
\hline \multicolumn{5}{|l|}{ Sociodemographic } \\
\hline \multicolumn{5}{|l|}{ Sex } \\
\hline Male & $1.03(0.94-1.12)$ & 0.53 & - & - \\
\hline Female & 1.00 & - & - & - \\
\hline \multicolumn{5}{|l|}{ Skin color } \\
\hline White & 1.00 & - & - & - \\
\hline Non-white & 1.01 & 0.78 & - & - \\
\hline \multicolumn{5}{|l|}{ Socioeconomic } \\
\hline \multicolumn{5}{|c|}{ Economic classification } \\
\hline$A B$ & $1.02(0.94-1.11)$ & 0.66 & - & - \\
\hline $\mathrm{CDE}$ & 1.00 & - & - & - \\
\hline \multicolumn{5}{|c|}{ Income (Brazilian Reais) } \\
\hline Until 500 & $0.92(0.84-1.00)$ & 0.06 & - & - \\
\hline $501-800$ & $0.98(0.90-1.07)$ & 0.66 & - & - \\
\hline$>800$ & 1.00 & - & - & - \\
\hline \multicolumn{5}{|l|}{ Education } \\
\hline Up to 4 years & $1.03(0.95-1.12)$ & 0.43 & - & - \\
\hline 5 years or more & 1.00 & - & & \\
\hline \multicolumn{5}{|l|}{ Type of service } \\
\hline FHS & $1.10(1.01-1.20)$ & 0.04 & $1.07(0.96-1.20)$ & 0.23 \\
\hline TPC & $0.91(0.83-0.10)$ & 0.04 & $0.85(0.75-0.97)$ & 0.01 \\
\hline $\mathrm{CHS}$ & 1.00 & - & & \\
\hline \multicolumn{5}{|l|}{ Social support } \\
\hline \multicolumn{5}{|l|}{ Conjugal situation } \\
\hline With partner & $1.01(0.94-1.08)$ & 0.80 & - & - \\
\hline Without partner & 1.00 & - & - & - \\
\hline \multicolumn{5}{|c|}{ Unemployment in the family } \\
\hline No & $0.98(0.90-1.06)$ & 0.57 & - & - \\
\hline Yes & 1.00 & - & - & - \\
\hline \multicolumn{5}{|l|}{ Health status } \\
\hline \multicolumn{5}{|l|}{ Hypertension } \\
\hline Yes & 1.00 & - & 1.00 & - \\
\hline No & $1.11(1.01-1.21)$ & 0.024 & $1.16(1.06-1.27)$ & 0.002 \\
\hline \multicolumn{5}{|l|}{ Diabetes } \\
\hline Yes & $1.10(0.99-1.23)$ & 0.069 & $1.16(1.04-1.29)$ & 0.008 \\
\hline No & 1.00 & - & 1.00 & - \\
\hline
\end{tabular}

95\%Cl: 95\% confidence interval; CHS: Community Health Service; FHS: Family Health Strategy; PR: prevalence ratio; TPC: Traditional Primary Care.

them, 1,449 had never used the services for this purpose. Alternatively, patients who are capable of surpassing the barrier of accessibility actually assess the use of the services in a very positive way. In this case, they all obtained mean scores above the optimal value established for this study (> 5.5). A study that evaluated comparatively FHS and "conventional" health care (CHC) using PCATool users and dentists' version, found positive results in favor to FHS services in relation to the attributes of PHC, and suggest that this services should be expanded 20.

For continuity, TPC was the oral health services that obtained a mean score below the minimum threshold, while FHS and CHS showed better results. Perhaps this is due to teams work process, 
which, regarding these services, relies on the presence of community health agents and has an indicator-based schedule.

The coordination of care, or the presence of some sort of continuity, as well as the identification of issues which are approached by other services, and the integration of care into the patient's general care 19, proved to be one of the weaknesses of services, given that it did not reach optimal levels for any of them. This attribute is dependent, in addition to teams, on the network established in the Municipality and shows, in addition to PHC, the struggles in providing secondary care in Porto Alegre, which currently has five Specialized Dental Care Services in operation, for a total of 157 OHT. This causes a major repressed demand and long waiting lines for having access to oral health appointments and moves us away from health care networks developed as "polyarchic organizations of sets of health services, tied together under a unique mission, common goals and relying on a cooperative and interdependent action, which allow to offer a continuous and comprehensive attention to a certain population, coordinated by PHC provided at the right moment, in the right place, with the right cost, with the proper quality and humanity" 21 (p. 2300).

Regarding comprehensiveness, which "implies that PHC units carry out arrangements to make sure that the patient receives all sorts of health care services, even if some may not be provided within them" 19 (p. 62), it can be assumed that CHS obtained the optimal level, the FHS a reasonable level and TPC a weak level, in relation to available services. For the services provided, they all obtained poor results, however the FHS was still statistically superior to the other two. This evidently shows that public oral care services have a lot of room for improvement. Based on these results, and considering the score for core attributes, it is then shown that CHS and FHS are superior to TPC, regarding the degree of orientation towards PHC.

In what concerns the ancillary domains from PHC, family centeredness and community orientation, one can notice that the extension of these attributes is quite low, showing the inability of OHT when it comes to transforming their practice into an integrated care. Some of the points can be signaled as major challenges for the establishment of a network that suits PHC. One is the permanent education and evaluation of teams, based on the difficulties found in the practice of these services. Another is the massive burden of disease in the territories and the pressure felt by the teams to meet the demand. There is also the population coverage issue, which is carried out by the teams. The calculation for an OHT varies from 3,000 to 6,000 people per team. However, it cannot be found, in official documents, indications about how this number was actually calculated. What can be found is an indication that the dentist must dedicate between $75 \%$ and $85 \%$ of their workload to clinic activities. This is regarded as an attempt to accommodate all restorative demands of the population under the responsibility of $\mathrm{OHT}$, nonetheless this also implies a fragmented work process, in which the dentists are unable to devote themselves to work focused on families and communities. A study evaluated the performance of oral health services related to procedures recommended in PHC, using data from PMAQ that included 18,114 PHC with OHT and found that a higher number of PHC services did not have an adequate infrastructure, however OHT that has oral health technicians or dentists with degrees in public health, shows better results in work processes and planned activities 22 .

The type of service used reveals an important increase in the prevalence of the high overall score of CHS in relation to FHS and TPC. The differences that benefit CHS units in PHC scores may be associated with some characteristics of this service, such as being training centers of human resources for SUS, through the Integrated Health Residency Program; all dental surgeons specialized in family and community health; a strong employment relationship, with low rotation in teams; many of them with experience in preceptorship. Data coverage from FHS shows that, at the beginning of this study, the city had 95 FHS teams with only 15 OHT assigned to a population of 1,409,351. In July 2015, these numbers became 179 FHS teams and 72 OHT. Nonetheless, these data do not match a real increase in terms of population coverage, since some of the primary care services were transformed into FHS, when they already provided the users with this sort of care. Such is the case of the CHS, which, from the Ruling n. 2,488 8, became 40 FHS teams and 20 OHT. This also took place with the TPC of the municipality, that changed the name, but not their work processes. In order to have data for comparison, the limit threshold of teams is 708, in other words, even with an increase in the number of teams, we are still four times below what we could have for FHS and between 5 and 10 times below for the OHT 13. A study that evaluated primary oral health care performance in Brazil from the PMAQ 
results include 10,334 OHT and found inequalities in the distribution of preventive dental procedures between macro-regions in Brazil, cities with a Human Development Index higher than 0.7 and cities with oral health coverage of up to 4,000 inhabitants per OHT. The authors concluded that the performance of preventive dental procedures remain low in Brazil 23.

In relation to health status (diabetes and hypertension), which maintained associated in multivariate analysis with higher overall scores of PHC attributes, it can be explained because there is a huge program in health services related to prevention and treatment of this chronic diseases and OHT are oriented to provide care to this population considering some oral health outcomes as risk factors for non-communicable diseases 24. A study that evaluated the perceptions from 37,262 users of PHC in relation to oral health care and treatments provided in SUS services, with data from PMAQ, that included questions related to needs for self-care, dental assistance during the treatment, and opinion about treatment received, found a good and very good homogeneous perception across Brazil 25.

The losses and refusals were higher than what was initially expected. The measures adopted to decrease the non-response bias had the intent to increase the number of visits to each household and replace all losses and refusals, to ensure the properties of the sample, according to the literature 26.

\section{Conclusions}

The results of this study show that there were differences among the services' evaluation of the PHC attributes in oral health services. The type of service was the most important variable associated with a high degree of orientation towards PHC, based on the experience of patients. This was the first study focused on the presence and degree of the attributes of PHC in oral health to use the validated instrument PCATool-OH. The results ratify that this instrument is capable of establishing differences between PHC services under different organizational arrangements, hence allowing to infer its applicability in other types of studies or scenarios, for instance, to investigate differences between OHT in urban and rural areas. In addition, more studies are necessary to investigate the differences among PHC services considering oral health.

\section{Contributors}

D. D. Cardozo and F. N. Hugo contributed to the study conception and design and data acquisition, analysis, and interpretation; drafting the article and revising it critically for important intellectual content; agreement to be accountable for all aspects of the work in ensuring that questions related to the accuracy and integrity of any part of the work are appropriately investigated and resolved.J. B. Hilgert contributed to the study conception and design and data analysis and interpretation; drafting the article and revising it critically for important intellectual content. C. Stein and E. Harzhein contributed to the drafting the article and revising it critically for important intellectual content. L. Hauser contributed to the study conception and design and data analysis and interpretation. All authors approved the final of the version of the paper.

\section{Additional informations}

ORCID: Débora Deus Cardozo (0000-0002-68524455); Juliana Balbinot Hilgert (0000-0002-22041634); Caroline Stein (0000-0003-4777-1630); Lisiane Hauser (0000-0003-3324-5533); Erno Harzhein (0000-0002-8919-7916); Fernando Neves Hugo (0000-0003-2222-7719).

\section{Acknowledgments}

This study is part of a project funded by the Rio Grande do Sul State Research Foundation (FAPERGS; notice Pesquisador Gaúcho, process 10/1553-2). C.S. hold a fellowship from the Brazilian Graduate Studies Coordinating Board (Capes); F.N.H. and J.B.H. hold a PQ-2 fellowship from the Brazilian National Research Council (CNPq). 


\section{References}

1. Silva JM, Caldeira AP. Modelo assistencial e indicadores de qualidade da assistência: percepção dos profi ssionais da atenção primária à saúde. Cad Saúde Pública 2010; 26:1187-93.

2. Backes MTS, Rosa LM, Fernandes GCM, Becker SG, Meirelles BHS, Santos SMA. Conceitos de saúde e doença ao longo da história sob o olhar epidemiológico e antropológico. Rev Enferm UERJ 2009; 17:111-7.

3. Cutolo LRA. Modelo biomédico, reforma sanitária e a educação pediátrica. ACM Arq Catarin Med 2006; 35:16-24.

4. Teixeira CF. A mudança do modelo de atenção à saúde no SUS: desatando nós, criando laços. In: Teixeira CF, Solla JP, editors. Modelo de atenção à saúde: promoção, vigilância e saúde da família. Salvador: Edufba; 2006. p. 19-58.

5. Departamento de Atenção Básica, Secretaria de Atenção à Saúde, Ministério da Saúde. Política Nacional de Atenção Básica. Brasília: Ministério da Saúde; 2012.

6. Departamento de Atenção Básica, Secretaria de Atenção à Saúde, Ministério da Saúde. Diretrizes da Política Nacional de Saúde Bucal. Brasília: Ministério da Saúde; 2004.

7. Ministério da Saúde. Portaria no 648/GM, de 28 de março de 2006. Aprova a Política Nacional de Atenção Básica, estabelecendo a revisão de diretrizes e normas para a organização da Atenção Básica para o Programa Saúde da Família (PSF) e o Programa Agentes Comunitários de Saúde (PACS). Diário Oficial da União 2006; 29 mar.

8. Ministério da Saúde. Portaria no 2.488, de 21 de outubro de 2011. Aprova a Política Nacional de Atenção Básica, estabelecendo a revisão de diretrizes e normas para a organização da Atenção Básica, para a Estratégia Saúde da Família (ESF) e o Programa de Agentes Comunitários de Saúde (PACS). Diário Oficial da União 2011; 24 out.

9. Bulgareli J, Cortellazzi KL, Ambrosano GMB, Meneghim MC, Faria ET, Mialhe FL, et al. Resolubility in oral health for primary care as an instrument for the evaluation of health systems. Ciênc Saúde Colet 2014; 19:383-91.

10. Instituto Brasileiro de Geografia e Estatística. Pesquisa Nacional por Amostra de Domicílios: análise de resultados, 1998. http://www.ibge. gov.br/home/estatistica/populacao/trabalhoe rendimento/pnad98/saude/analise.shtm (accessed on 17/Aug/2011).

11. Narvai PC. Mais dentistas? Jornal do Site Odonto 2018. https://www.jornaldosite.com. $\mathrm{br} /$ arquivo/anteriores/capel/capel6.htm (accessed on 06/May/2019).

12. Ministério da Saúde. Portaria no $1.444 / G M$, de 28 de dezembro de 2000. Estabelece incentivo financeiro para a reorganização da atenção à saúde bucal prestada nos municípios por meio do Programa de Saúde da Família. Diário Oficial da União 2000; 29 dez.
13. Ministério da Saúde. Sala de Apoio à Gestão Estratégica. http://sage.saude.gov.br/ (accessed on 01/Sep/2015).

14. Grupo Hospitalar Conceição. Saúde Comunitária. https://www.ghc.com.br/default.asp?id Menu $=$ unidades\&idSubMenu $=5$ (accessed on 08/Apr/2013).

15. Castro RCL, Knauth DR, Harzheim E, Hauser L, Duncan BB. Avaliação da qualidade da atenção primária pelos profissionais de saúde: comparação entre diferentes tipos de serviços. Cad Saúde Pública 2012; 28:1772-84.

16. Oliveira M. Presença e extensão dos atributos da atenção primária à saúde entre os serviços de atenção primária em Porto Alegre: uma análise agregada [Masters Thesis]. Porto Alegre: Faculdade de Medicina, Universidade Federal do Rio Grande do Sul; 2007.

17. Baldani MH, Rocha JS, Fadel CB, Nascimento AC, Antunes JLF, Moyses SJ. Assessing the role of appropriate primary health care on the use of dental services by Brazilian low-income preschool children. Cad Saúde Pública 2017; 33:e00158116.

18. Associação Brasileira de Empresas de Pesquisa. Critério de Classificação Econômica Brasil. http://www.abep.org/codigos-e-guias-daabep (accessed on 06/May/2019).

19. Starfield B. tenção primária: equilíbrio entre necessidades de saúde, serviços e tecnologia. Brasília: Organização das Nações Unidas para a Educação, a Ciência e a Cultura/Ministério da Saúde; 2002.

20. Nascimento AC, Moyses ST, Werneck RI, Gabardo MCL, Moyses SJ. Assessment of public oral healthcare services in Curitiba, Brazil: a cross-sectional study using the Primary Care Assessment Tool (PCATool). BMJ Open 2019; 9:e023283.

21. Mendes EV. Health care networks. Ciênc Saúde Colet 2010; 15:2297-305.

22. Baumgarten A, Hugo FN, Bulgarelli AF, Hilgert JB. Curative procedures of oral health and structural characteristics of primary dental care. Rev Saúde Pública 2018; 52:35.

23. Neves M, Giordani JM, Ferla AA, Hugo FN. Primary care dentistry in Brazil: from prevention to comprehensive care. J Ambul Care Manage 2017; 40 Suppl 2:S35-48.

24. Departamento de Atenção Básica, Secretaria de Atenção à Saúde, Ministério da Saúde. A saúde bucal no Sistema Único de Saúde. http://bvsms.saude.gov.br/bvs/publicacoes/ saude_bucal_sistema_unico_saude.pdf (accessed on 06/May/2019).

25. Baumgarten A, Da Veiga RS, Bulgarelli PT, Diesel VM, Bulgarelli AF. Perceptions of primary health care service users regarding dental team practices in Brazil. Prim Health Care Res Dev 2018; 19:309-15.

26. Silva NN. Amostragem probabilística: um curso introdutório. São Paulo: Edusp; 2004. 


\section{Resumo}

O estudo buscou comparar a presença e abrangência de atributos da atenção primária em saúde (APS) em serviços de saúde bucal, de acordo com três diferentes arranjos organizacionais de APS: Estratégia Saúde da Família (ESF), Serviço de Saúde Comunitária (SSC) e Atenção Primária Tradicional (APT). O estudo transversal foi realizado entre 2011 e 2013, adotando uma estratégia de amostragem aleatória em clusters. Foram entrevistados adultos usuários de 15 serviços de saúde, sendo 6 do SSC, 4 da ESF e 5 da APT, e que mantinham a mesma equipe de saúde bucal há pelo menos dois anos. A amostra final consistiu em 407 usuários, entrevistados com o instrumento Primary Care Assessment Tool - Oral Health of Adults e com um questionário sociodemográfico. As pontuações de APS foram calculadas e transformadas em uma escala de 0 a 10. Para as pontuações altas, foi utilizado o ponto de corte de $>$ 5,5. Nos três tipos de serviços, a maioria dos entrevistados era do sexo feminino. Em quase todos os atributos, o desempenho dos SSC e da ESF foi superior àquele da APT $(p<0,05)$. A abrangência dos atributos de APS foi baixa (a pontuação mais alta foi 5,75, no SSC). O SSC foi o único serviço em que a metade dos usuários $(83 ; 49,1 \%)$ avaliou os serviços de saúde bucal com pontuação geral alta para APS. Conclui-se que havia diferenças entre os arranjos organizacionais de APS nos serviços de saúde bucal, mas há muito a melhorar na orientação dos serviços odontológicos na APS. São necessários mais estudos para avaliar as diferenças nos serviços de APS desde a perspectiva da saúde bucal.

Atenção Primária à Saúde; Saúde Bucal; Avaliação de Serviços de Saúde; Serviços de Saúde Bucal

\section{Resumen}

El objetivo era comparar la presencia y extensión de la atención primaria de salud (APS) en cuanto a los servicios orales de salud oral, desde los atributos de la APS, según los tres tipos diferentes de modelos organizativos: Estrategia Salud de la Familia (ESF), Servicios Comunitarios de Salud (SCS) y Atención Primaria Tradicional (APT). Este es un estudio transversal que se llevó a cabo entre 20112013, siguiendo una estrategia de muestreo aleatorio por conglomerados. Los usuarios adultos fueron entrevistados en 15 servicios de salud, donde 6 estaban gestionados por SCS, 4 por ESF y 5 por APT y que habian contado con el mismo equipo de salud oral durante al menos dos años. La muestra final fue de 407 usuarios entrevistados, usando la herramienta de evaluación Primary Care Assessment Tool - Oral Health of Adults, así como un cuestionario sociodemográfico. Las puntuaciones de APS se calcularon y transformaron en una escala en un rango de 0 a 10. Para las puntuaciones más altas, se utilizó el punto de corte > 5.5. La mayoría de los entrevistados fueron mujeres en los tres tipos de servicios. El desempeño de los SCS y ESF fue mayor que en la APS en casi todos los atributos $(p<0,05)$. La extensión de los atributos de la APS en servicios fue escasa (la puntuación general más alta fue 5,75 en SCS). El SCS fue el único servicio con la mitad de usuarios (83; 49,1\%) servicios cualificados de salud bucal, contando con una puntuación general alta para APS. Por lo que se concluye que existen diferencias entre los modelos organizativos de APS, respecto a los servicios orales de salud. No obstante, hay muchas cosas que deben ser mejoradas en la orientación de los servicios orales de salud relacionados con la APS. Se necesitan más estudios para evaluar las diferencias en los servicios de APS en relación con la salud bucal.

Atención Primaria de Salud; Salud Bucal; Evaluación de Servicios de Salud; Servicios de Salud Dental
Submitted on $08 / \mathrm{Jan} / 2019$

Final version resubmitted on 14/Jun/2019

Approved on 08/Jul/2019 
Cardozo DD, Hilgert JB, Stein C, Hauser L, Harzheim E, Hugo FN. Presence and extension of the attributes of primary health care in public dental services in Porto Alegre, Rio Grande do Sul State, Brazil. Cad Saúde Pública 2020; 36(2):e00004219.

doi: 10.1590/0102-311XER004219

Where it reads:

Débora Deus Cardozo 1

Juliana Balbinot Hilgert 1

Caroline Stein 1

Lisiane Hauser 1

Erno Harzhein 1

Fernando Neves Hugo 1

It should read:

Débora Deus Cardozo 1

Juliana Balbinot Hilgert 1

Caroline Stein 1

Lisiane Hauser 1

Erno Harzheim 1

Fernando Neves Hugo 1 